Volume 3

Number 1 July

7-31-2019

\title{
Foreword from Editor in Chief - 5th Edition
}

Herdis Herdiansyah

Universitas Indonesia, herdis@ui.ac.id

Follow this and additional works at: https://scholarhub.ui.ac.id/ajce

Part of the Social and Behavioral Sciences Commons

\section{Recommended Citation}

Herdiansyah, Herdis (2019). Foreword from Editor in Chief - 5th Edition. ASEAN Journal of Community Engagement, 3(1).

Available at: https://doi.org/10.7454/ajce.v3i1.199

Creative Commons License

c) (i) (2)

This work is licensed under a Creative Commons Attribution-Share Alike 4.0 License.

This Research Article is brought to you for free and open access by the Universitas Indonesia at ASEAN Journal of Community Engagement. It has been accepted for inclusion in ASEAN Journal of Community Engagement. 


\section{ASEAN Journal of Community Engagement}

\section{Foreword from Editor in Chief Herdis Herdiansyah}

\section{Greetings!}

The Fifth Edition of ASEAN Journal of Community Engagement (AJCE) has been published on July 2019. After the process has been through from submitted until accepted, we from Editorial Board concluded that for the second edition of AJCE present eight manuscripts that have an excellent quality of applied science articles and spread within Indonesia and Philippines. Besides these articles, there is a lesson learn from community engagement program that has been done in the field.

For this edition there is a change from author guidelines. This guideline is regenerated since publication from December 2018. So the manuscript from December 2018 is following this Author Guidelines. Also, our manuscript is proofread assisted by Management Office of Product Research and Innovation (KPPRI) Universitas Indonesia.

Finally, I am as the Chief Editor of the ASEAN Journal of Community Engagement wishing a great pleasure to publish this journal for academic interest. 